\title{
Isolation and Evaluation of Microalgae from Mangrove Area in South Coast of Sao Paulo (Brazil) for Lipid Production
}

\author{
Marcelo Chuei Matsudo ${ }^{1,2 *}$, Célia Leite Sant'Anna ${ }^{3}$, Lina Susana Pérez-Mora ${ }^{1}$, \\ Roberta Claro da Silva ${ }^{4}$ and João Carlos Monteiro de Carvalho ${ }^{1}$
}

${ }^{1}$ University of Sao Paulo, Faculty of Pharmaceutical Sciences, Department of Biochemical and Pharmaceutical Technology, Av. Prof. Lineu Prestes 580,

Bl. 16, 05508-900, São Paulo-SP, Brazil

${ }^{2}$ Federal University of Itajubá, Institute of Natural Resources, Av. Benedito Pereira dos

Santos, 1303, 37500-903, Itajubá, M.G, Brazil

${ }^{3}$ Institute of Botany, Avenida Miguel Estéfano 3687, 04301-012 São Paulo, SP, Brazil

${ }^{4}$ North Carolina Agricultural and Technical State University, Department of Family and Consumer Sciences, 1601 E. Market Street, Greensboro, NC, 27411, USA

*Corresponding author

\section{A B S T R A C T}

\section{Keywords}

isolation; biomass; fatty acids, lipids; single cell oil; microalgae

Article Info

Accepted:

18 May 2020

Available Online:

10 June 2020
Microalgae may be considered as the main alternative source of valuable biomolecules for several commercial applications, such as food and energy. This study sought to evaluate photosynthetic microorganisms isolated from fresh water in mangrove areas of southern Coast of Sao Paulo State (Brazil). After cultivation in Erlenmeyer flasks, 9 green algae and 2 cyanobacteria strains had their biomass analyzed in terms of total protein, lipid contents, and fatty acids profile. Total protein content varied in the range of 13.25 to $32.47 \%$ and total lipid content varied in the range of 15.27 to $38.11 \%$. Among several fatty acids, palmitic acid (C16:0), linoleic acid (C18:2n6), and $\gamma$-linolenic acid (C18:3n6) were the most abundant ones. Depending on the strain, not only protein for food supplement can be obtained but also polyunsaturated fatty acid for nutraceutical or saturated lipids for biodiesel could be obtained from these isolated microalgae.

\section{Introduction}

Microalgae are one of the most important natural and alternative sources of valuable biomolecules that could meet the growing needs in food, energy, etc. (Barka and Blecker 2016). Microalgae have a higher level of productivity than traditional crops and can be grown in different climatic conditions, such as desert and coastal areas (Christaki et al., 2011). Several authors stress that microalgae could be an appropriate alternative feedstock for next generation biofuels for replacing or complementing current sources, such as 
rapeseed, soybean, sunflower and palm (Chisti 2007; Gouveia and Oliveira 2009; Huang et al., 2010). On the other hand, microalgae are also highlighted for the number of bioactive compounds (fatty acids, carotenoids, vitamins, proteins, etc.) that could be provided by its biomass to be used in food, cosmetics and pharmaceutical industries (Olaizola 2003; Pulz and Gross 2004; Gouveia et al., 2009; Matos et al., 2017).

Up to date, more than 30,000 microalgae species have been classified (Norton et al., 1996). However, commercial attainments of microalgal biotechnology seems to be very modest, since few hundred of microalgal species have been studied for biochemical content and a couple of them have been cultivated in commercial scale (Olaizola 2003).

The aim of this study was to evaluate the potential of microalgae as source of oil rich biomass. 9 (nine) green algae and 2 (two) cyanobacteria strains were isolated from fresh water in mangrove areas of Southern Coast of Sao Paulo State, and cultivated in the laboratory for analyzing lipid content and fatty acids profile.

\section{Materials and Methods}

\section{Sample collection and isolation}

Using sterile glass bottles $(1 \sim 2$ L), fresh water samples were collected in different mangrove areas within "Serra do Mar" State Park located in the cities of Cananeia andPeruíbe (Southern Coast of Sao Paulo State - Brazil). Geographical coordinates are shown in Table 1. Concomitantly with the collection of samples, temperature and $\mathrm{pH}$ (pH-indicator strips; Merck) were measured.

At the laboratory, water samples (containing microalgae species) were used to inoculate enriched standard culture media: BOLD (UTEX n.d.), CHU (UTEX n.d.), Schlösser (Schlösser 1982), and F/2 (Guillard and Ryther 1962). When the culture became visually greenish, the isolation took place by combining micropipette method and streaking cell across agar plates (Andersen and Kawachi 2005).

\section{Isolates identification}

Identifications were based on microscopic morphology of the individual cells and colonial characteristics. under light microscope (Olympus system microscope model BX51) and images were captured with camera Olympus SC30.

\section{Cultivation of isolate strains}

All the isolated strains were cultivated in BOLD medium, with the exception of cyanobacterial strains, which have grown in Schlosser medium. These photosynthetic microorganisms were grown in 6L Erlenmeyer flasks containing $3 \mathrm{~L}$ of culture medium. Filtered air was continuously injected with the use of air stone diffuser. Room temperature was adjusted to $25{ }^{\circ} \mathrm{C}$ and 30W fluorescent lamps were positioned above the flasks for providing light intensity of 60 $\mu$ mol photons. $\mathrm{m}^{-2} . \mathrm{s}^{-1}$. Initial $\mathrm{pH}$ was adjusted to 7.0. Cell growth was indirectly measured by optical density at $550 \mathrm{~nm}$ (Becker 1994) using a spectrophotometer (Femto 700 Plus). Cultivation was ended when optical density values showed to be stable.

\section{Microalgal biomass evaluation}

At the ended of each cultivation, biomass was recovered by centrifugation, washed twice with distilled water, and dried at $55{ }^{\circ} \mathrm{C}$ for 12h. Dry biomass was submitted to determination of total lipids, employing organic solvents (chloroform:methanol 2:1, 
$\mathrm{v} / \mathrm{v}$ ) in Soxhlet extractor (Piorreck et al., 1984; Olguín et al., 2001). Lipid fraction, recovered with petroleum ether, was submitted to analysis of fatty acids content, after conversion to corresponding methyl esters (Hartman and Lago 1973). The analysis of fatty acid methyl esters (FAME) was performed in a gas chromatograph (Agilent Model 7890 CX) in accordance with Rodrigues-Ract and Gioelli (Ract and Gioielli 2008) and Perez-Mora et al., (Pérez-Mora et al., 2016). FAME components were identified by comparing their retention time with the standard 37 FAME mix (Supelco).

Additionally, total protein content was analyzed by the Kjeldahl method, using factor 6.25 for converting from total nitrogen content (AOAC 1984).

\section{Results and Discussion}

Table 1 shows data from collection sites, where it is possible to see that $\mathrm{pH}$ values were within 6.5 and 7.0 and temperature values were in the range 21.5 24.5. At the laboratory (in the same day), samples were used to inoculate 4 different medium generally used for the cultivation of microalgae: BOLD (UTEX n.d.), CHU (UTEX n.d.), Schlosser (Schlösser 1982), and F/2 (Guillard and Ryther 1962). Within 2 or 3 weeks, some of the cultures became greenish, indicating microalgal growth. More intense color was presented in medium BOLD and Schlosser.

These mixed cultures were used for isolation of 11 microalgae strains (9 from chlorophyceae group and 2 from cyanobacteria group). The identification of each strain was performed by microscopic identifications based on morphological characteristics, and the results are shown in Table 2.Figure 1 shows isolated microalgal strain from Estação Ecológica Juréia-Itatins (Ubatuba - S.P.) and Parque Estadual da Ilha do Cardoso (Cananéia - S.P.). All these strains were deposited in the Culture Collection of Freshwater Microalgae of the Federal University of São Carlos (CCMAUFSCar). Some of the main characteristics are presented below:

Synechocystis salina (Sauvageau 1892)(Fig. 1A). Unicellular, slightly widely oval to cylindrical. Cell division in two perpendicular planes in successive generations. Daughter cells grow until reaching the original size and shape of the mother cell before next binary fission.

Monoraphidium circinale (KomárkováLegnerová 1969) (Fig. 1B). Crescentshaped cells with elongate ends, without mucilaginous envelope. Smooth cell walls. Uninucleate cells with a parietal chloroplast.

Synechocystis salina (Sauvageau 1892)(Fig. 1C). Agglomerated or solitary cells without common mucilage. Spherical or oval cells. Daughter cells separate quickly after division and grow to the original size and shape of mother cell before next binary fission.

Chlorella vulgaris (Beijerinck 1890) (Fig.1D). Colonies are formed by spherical cells and without mucilage. Only one parietal chloroplast for each single cell.

Chlorella sp. (Beijerinck 1890)(Fig.1E). subspherical or ellipsoid cells with a parietal chloroplast.

Chlorella minutissima (Fott and Nováková 1969) (Fig.1F). This species of the genus Chlorella can be distinguished from other Chlorella species by its small size (this difficult to see cell details). Spherical to oval cells are bounded by a thin cell wall, containing a single nucleus and a chloroplast.

Chlorella sp. (Beijerinck 1890) (Fig.1G). Colonies are formed by spherical cells 
and without mucilage and another solitary cells. Only one parietal chloroplast for each single cell. Sporangia with different numbers of autospores.

Chlorella sp. (Beijerinck 1890) (Fig.1H). Spherical to subspherical cells, single or forming colonies. One parietal chloroplast.

Coenochloris sp. (Korshikov 1953) (Fig.1I). Spherical or oval to cylindrical cells, with smooth cell walls. Uninucleate cells, with parietal cup-shaped or lobed chloroplast.

Choricystis cf. guttula(Fott 1976; Hindák 1980) (Fig. 1J). Oval to reniform or pyriform cells, with smooth cell walls, without mucilage envelope. Uninucleate cells with one parietal chloroplast and complete absence of pyrenoids in the chloroplasts.

Chlorella minutissima (Fott and Nováková 1969) (Fig. 1K). Small, spherical, and oval cells, bounded by a thin cell wall, with a single nucleus and a chloroplast.

Isolated strains were cultivated in 6L Erlenmeyer flasks with 3L of BOLD medium (microalgae) or Schlosser medium (cyanobacteria). When stationary phase took place $(20 \sim 30$ days), each biomass was harvested, dried and submitted to analysis of total lipid content and total protein content (Table 3). Total lipid content varied in the range $15.27 \%$ to $38.11 \%$. Isolates $\mathrm{C} 1-\mathrm{Ci}$ (Synechocystis salina), C3-CA (Monoraphidium circinale) and J1-2A (Choricystiscf. guttula) showed lipid content higher than $30 \%$, in a biomass obtained in not optimized conditions for obtaining single cell lipids. There are several studies in the literature showing that it is possible to manipulate cultivation conditions aiming to increase lipid content in biomass(Chen et al., 2013; Ochsenreither et al., 2016). These strains represent good candidates for studies about optimization of cultivation conditions with this purpose.

With biotechnological approaches, cell lipid content may be increased, reaching values much higher than that observed in plants used for the production of biodiesel, like soybean and oil palm(Chisti 2008).

According to Becker (Becker 1994), high protein content was one of the main reasons for considering photosynthetic microorganisms as source of protein. In the isolates of the present study, total protein content varied from $13.25 \%$ to $32.47 \%$. These values may be considered as very low, comparing with values pointed out by Becker (Becker 1994) or Barka \& Blecker(Barka and Blecker 2016). However, further studies related to adequate provision of nitrogen source could allow the increase in protein content of these microalgae, as stressed by Matsudo et al., (Matsudo et al., 2012) in the continuous cultivation of the cyanobacterium Arthrospira platensis.

Lipid fraction was recovered in petroleum ether and, after conversion to corresponding methyl esters, gas chromatograph was employed for the analysis of fatty acid methyl esters (FAME). The fatty acids profiles of each isolate species are presented in Table 4. It is possible to observe that palmitic acid (C16:0), linoleic acid (C18:2n6) and $\gamma$ linolenic acid (C18:3n6) were present in all isolates. Guedes et al., (Guedes et al., 2011) also showed that these three fatty acids were the most abundant ones in Chlorella vulgaris biomass. 
Table.1 Collection sites at Estação Ecológica Juréia-Itatins (J) in the city of Peruíbe(S.P.) and Parque EstadualIlha do Cardoso (C) in the city of Cananéia (S.P.)

\begin{tabular}{|c|c|c|c|c|c|}
\hline $\begin{array}{c}\text { Collection } \\
\text { site }\end{array}$ & Date / Time & Temperature & pH & Latitude S & Longitude W \\
\hline $\mathbf{J 1}$ & $05 / 25 / 2012 / 9: 40$ & $24.5^{\circ} \mathrm{C}$ & 7.0 & -24.557 & -47.229 \\
\hline $\mathbf{J 2}$ & $05 / 25 / 2012 / 10: 07$ & $21.5^{\circ} \mathrm{C}$ & 6.5 & -24.530 & -47.191 \\
\hline $\mathbf{J 3}$ & $05 / 25 / 2012 / 10: 56$ & $23.0^{\circ} \mathrm{C}$ & $6.5 \sim 7.0$ & -24.467 & -47.113 \\
\hline $\mathbf{J 4}$ & $05 / 25 / 2012 / 11: 37$ & $23.5^{\circ} \mathrm{C}$ & $6.5 \sim 7.0$ & -24.436 & -47.093 \\
\hline $\mathbf{C 1}$ & $06 / 03 / 2012 / 11: 11$ & $23.0^{\circ} \mathrm{C}$ & 7.0 & -25.0773 & -47.9388 \\
\hline $\mathbf{C 3}$ & $06 / 03 / 2012 / 12: 09$ & $23.5^{\circ} \mathrm{C}$ & 7.0 & -25.0195 & -47.9271 \\
\hline
\end{tabular}

J1: Verde River; J2: Grajaúna River; J3: Barra Velha River; J4: Una River; C1: Sítio Grande River; C3: Olaria River.

Table.2 List of isolates from Estação Ecológica Juréia-Itatins (J) in the city of Peruíbe (S.P.) and Parque Estadual da Ilha do Cardoso (C) in the city of Cananéia (S.P.)

\begin{tabular}{|l|l|l|l|l|}
\hline Ourcode & Organism & Medium & Phylum & Accesion number \\
\hline C1-Ci & Synechocystis salina & BOLD & Cyanobacteria & CCMA-UFSCar 691 \\
\hline C3-CA & Monoraphidium circinale & BOLD & Chlorophyta & CCMA-UFSCar 690 \\
\hline J2-5A-i2 & Synechocystis salina & BOLD & Cyanobacteria & CCMA-UFSCar 692 \\
\hline J2-C2A-i2 & Chlorella vulgaris & BOLD & Chlorophyta & CCMA-UFSCar 689 \\
\hline J3-9A & Chlorella sp. & BOLD & Chlorophya & CCMA-UFSCar 700 \\
\hline J4-3B & Chlorella minutissima & SCHLÖSSER & Chlorophyta & CCMA-UFSCar 708 \\
\hline J2-3B & Chlorella sp. & BOLD & Chlorophyta & CCMA-UFSCar 706 \\
\hline J2-4A & Chlorella sp. & BOLD & Chlorophyta & CCMA-UFSCar 709 \\
\hline J3-10B & Coenochloris sp. & BOLD & Chlorophyta & CCMA-UFSCar 707 \\
\hline J1-2A & Choricystis cf. guttula & BOLD & Chlorophyta & CCMA-UFSCar 710 \\
\hline J1-1B & Chlorella minutissima & SCHLÖSSER & Chlorophyta & CCMA-UFSCar 705 \\
\hline
\end{tabular}

Table.3 Total lipid and total protein contents in the biomass of isolated strains

\begin{tabular}{|l|c|c|}
\hline Strain & $\begin{array}{c}\text { Total Lipid } \\
(\%)\end{array}$ & $\begin{array}{c}\text { Total Protein } \\
(\%)\end{array}$ \\
\hline C1-Ci: Synechocystis salina & $38.11 \pm 1.81$ & $25.90 \pm 0.54$ \\
\hline C3-CA: Monoraphidium circinale & $32.27 \pm 0.34$ & $26.98 \pm 2.20$ \\
\hline J2-5A-i2: Synechocystis salina & $17.09 \pm 0.41$ & $21.82 \pm 2.81$ \\
\hline J2-C2A-i2: Chlorella vulgaris & $25.89 \pm 1.17$ & $13.25 \pm 1.73$ \\
\hline J3-9A: Chlorella sp. & $28.54 \pm 1.60$ & $22.58 \pm 2.63$ \\
\hline J2-3B: Chlorella sp. & $18.97 \pm 2.13$ & $22.38 \pm 1.20$ \\
\hline J2-4A: Chlorella sp. & $22.69 \pm 0.6$ & $24.61 \pm 0.12$ \\
\hline J3-10B: Coenochloris sp. & $19.20 \pm 1.13$ & $17.23 \pm 1.49$ \\
\hline J1-1B: Chlorella minutissima & $15.27 \pm 1.40$ & $27.79 \pm 1.86$ \\
\hline J4-3B: Chlorella minutissima & $16.34 \pm 4.60$ & $21.35 \pm 0.34$ \\
\hline J1-2A: Choricystis cf. guttula & $35.89 \pm 5.78$ & $32.47 \pm 0.83$ \\
\hline
\end{tabular}


Table.4 Fatty acids profiles found in the isolated species

\begin{tabular}{|c|c|c|c|c|c|c|c|c|c|c|c|}
\hline $\begin{array}{c}\text { Fatty } \\
\text { acid }(\%)^{\mathbf{a}}\end{array}$ & $\begin{array}{c}\text { Synechocystis } \\
\text { salina } \\
\text { C1-Ci }\end{array}$ & $\begin{array}{c}\text { Monoraphidium } \\
\text { circinale } \\
\text { C3-CA }\end{array}$ & $\begin{array}{c}\text { Synechocystis } \\
\text { salina } \\
\text { J2-5A-i2 }\end{array}$ & $\begin{array}{c}\text { Chlorella } \\
\text { vulgaris } \\
\text { J2-C2A- } \\
\text { i2 }\end{array}$ & $\begin{array}{c}\text { Chlorella } \\
\text { sp. } \\
\text { J3-9A }\end{array}$ & $\begin{array}{c}\text { Coenochloris } \\
\text { sp. } \\
\text { J3-10B }\end{array}$ & $\begin{array}{c}\text { Chlorella } \\
\text { minutissima } \\
\text { J4-3B }\end{array}$ & $\begin{array}{l}\text { Choricystis cf. } \\
\text { guttula J1-2A }\end{array}$ & $\begin{array}{c}\text { Chlorella } \\
\text { minutissima } \\
\text { J1-1B }\end{array}$ & $\begin{array}{c}\text { Chlorella } \\
\text { sp. } \\
\text { J2-3B }\end{array}$ & $\begin{array}{c}\text { Chlorella } \\
\text { sp. } \\
\text { J2-4A }\end{array}$ \\
\hline C11:0 & - & - & 5.10 & - & - & 0.85 & - & - & - & 1.09 & - \\
\hline N.I. ${ }^{b}$ & - & - & 3.24 & - & - & - & - & - & - & - & - \\
\hline C12:0 & - & - & - & - & - & - & - & 3.58 & - & 0.46 & 1.43 \\
\hline C16:0 & 30.85 & 22.61 & 53.73 & 28.33 & 24.59 & 29.01 & 16.83 & 21.43 & 26.74 & 26.22 & 23.16 \\
\hline N.I. ${ }^{b}$ & - & 3.68 & - & - & - & 6.93 & 7.56 & - & - & - & 13.32 \\
\hline C16:1 & - & - & 6.87 & 2.36 & - & - & - & - & - & - & - \\
\hline N.I. ${ }^{b}$ & - & 3.82 & - & 1.67 & 9.29 & - & 17.50 & 3.98 & 16.98 & 10.68 & - \\
\hline C17:1 & - & - & - & 4.70 & 9.33 & 5.66 & - & 1.78 & - & 4.66 & 6.04 \\
\hline N.I. ${ }^{b}$ & 9.57 & 6.60 & - & 1.89 & - & - & - & - & - & - & 3.12 \\
\hline C18:0 & - & - & - & - & - & - & - & 3.79 & 1.69 & - & - \\
\hline C18:1n9c & 12.22 & 21.85 & 5.99 & 36.19 & 5.32 & 6.18 & 3.69 & 31.93 & 15.97 & 4.09 & - \\
\hline C18:2n6c & 17.01 & 20.84 & 14.29 & 9.73 & 29.63 & 31.79 & 45.63 & 24.29 & 31.09 & 35.00 & 35.24 \\
\hline C18:3n6 & 24.74 & 16.10 & 1.47 & 13.26 & 21.86 & 17.28 & 8.82 & 9.4 & 7.54 & 14.29 & 14.66 \\
\hline N.I. ${ }^{b}$ & 5.63 & 4.50 & - & 2.27 & - & - & - & - & - & - & - \\
\hline C20:3n6 & - & - & - & - & - & 2.32 & - & - & - & 3.53 & 3.06 \\
\hline
\end{tabular}

${ }^{\text {a }}$ Percentage of fatty acids relative to the total content (weight/weight).

${ }^{\mathrm{b}}$ Unidentified compound. Absent in 37 MIX patterns.

C11:0 undecanoic acid; C12:0 lauric acid; C16:0 palmitic acid; C16:1 palmitoleic acid; C17:1 cis-10-heptadecenoic acid;

C18:0 stearic acid; C18:1n9 oleic acid; C18:2n6 linoleic acid; C18:3n6 $\gamma$-linolenic acid; C20:3n6 eicosatrienoic acid.

- : Not detected 


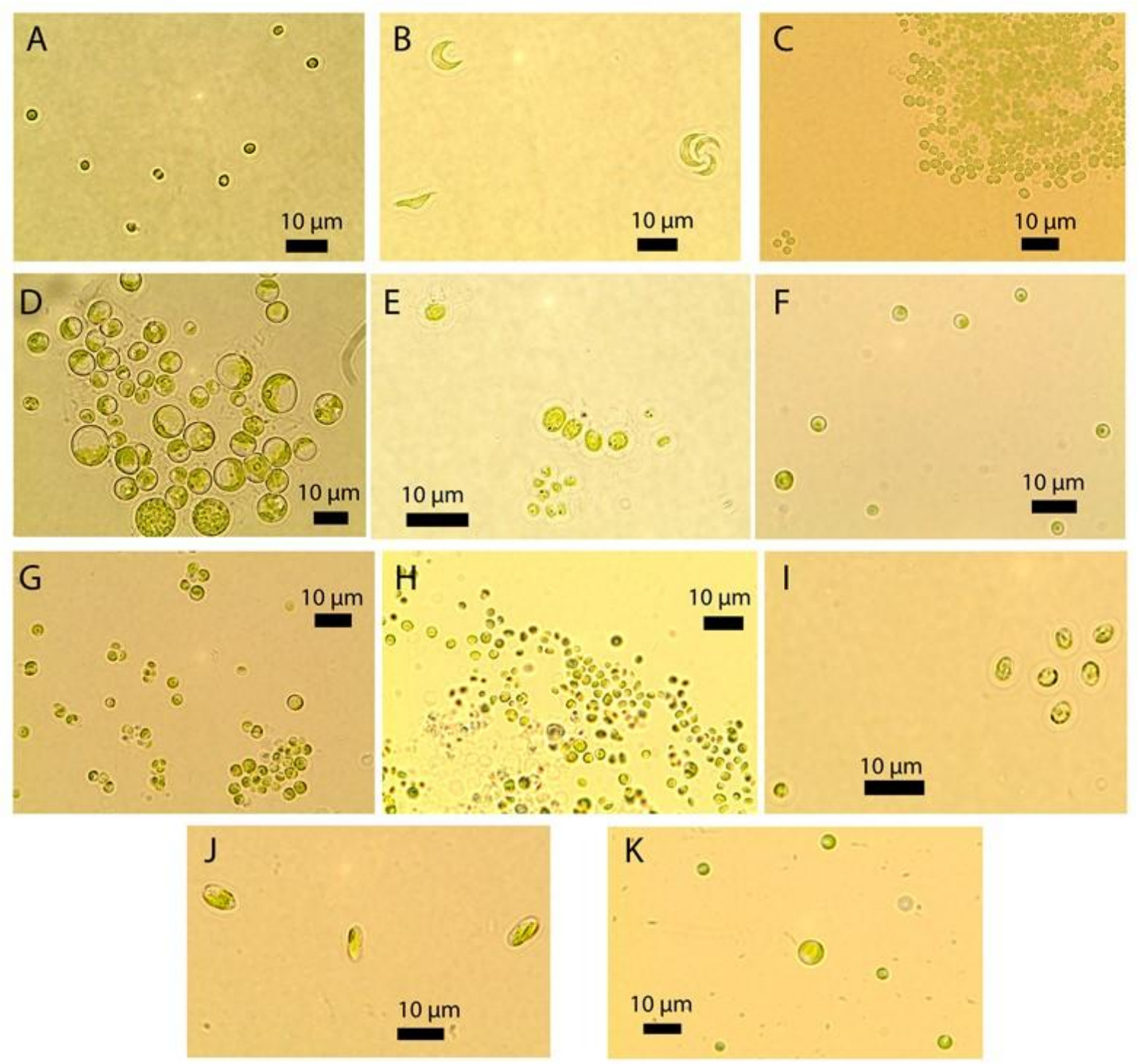

Figure.1 Photomicrographsofisolatedmicroalgalstrainfrom Estação Ecológica Juréia-Itatins (Ubatuba - S.P.) and Parque Estadual da Ilha do Cardoso (Cananéia - S.P.).A: Synechocystis salina; B: Monoraphidium circinale; C: Synechocystis salina;D: Chlorella vulgaris; E: Chlorella sp.; F: Chlorella minutíssima; G: Chlorella sp.; H: Chlorella sp.; I: Coenochloris sp.; J: Choricystiscf. guttula; K: Chlorella minutissima

Linoleic acid (C18:2n6) is known to be essential fatty acid for humans, and it reached values over $30 \%$ in $\mathrm{J} 3-10 \mathrm{~B}$ (Coenochloris sp.), J1-1B (Chlorella minutissima), and J23B (Chlorella sp.), and over 45\% in J4-3B (Chlorella minutissima). $\gamma$-linolenic acid (C18:3) reached values over $20 \%$ in $\mathrm{C} 1-\mathrm{Ci}$ (Synechocystis salina) and J3-9A-B (Chlorella sp.). The importance of these 2 fatty acids (linoleic acid and $\gamma$-linolenic acid) is justified by the fact that they are precursors of arachidonic acid, which in turn participate in the synthesis of eicosanoids in human body (Verlengia and Lima 2002).

Eicosanoids, produced with the use of $\omega-6$ fatty acids, are biochemical mediators in processes related to inflammation, infection, tissue injury, immune system modulation, and platelet aggregation (Kus et al., 2011). 
Although $\gamma$-linolenic acid may be synthesized in human body by the linoleic acid, an enzyme deficiency in delta-6- desaturase may result in the need of supplementation of this fatty acid (Horrobin 1992). Linoleic acid has been discovered as essential fatty acid in no more than a century ago and, since then, it has been exhaustively studied concerning health benefits.

Moreover, its concentration is very low in meat, milk and their derivatives for attaining these benefits(Santos-zago et al., 2008).Therefore, microalgal biotechnology seems to be a very promising technology to meet the probably increasing demand in the future.

Considering the application in biodiesel, it is well known that saturated fatty acids is preferable than unsaturated fat acids mainly because of superior oxidative stability ( $\mathrm{Hu}$ et al., 2008). In this sense, the isolate J2-5A-i2 (Synechocystis salina) seems to be one of the best strains for this application, since more than $50 \%$ of its fatty acids are saturated, although its lipid content is one of the lowest in this study.

In the present work, nine green algae and two cyanobacteria strains were isolated from fresh water in mangrove areas of southern Coast of Sao Paulo State (Brazil). By the biochemical analyses of their biomass, it was possible to observe total protein content in the range of 13.25 to $32.47 \%$ and total lipid content in the range of 15.27 to $38.11 \%$. Among several fatty acids, palmitic acid (C16:0), linoleic acid (C18:2n6), and $\gamma$-linolenic acid (C18:3n6) were the most abundant ones. Depending on the strain, not only protein for food supplement can be obtained but also polyunsaturated fatty acid for nutraceutical or saturated lipids for biodiesel could be obtained by these isolated microalgae.

\section{Acknowledgements}

The authors thank CAPES (Coordenação de Aperfeiçoamento de Pessoal de Nível Superior - Brasil - finance code 001) and Fapesp (Fundação de Amparo à Pesquisa do Estado de São Paulo) for grant10/51503-4. We also thank Estação Ecológica de Juréia Itatins (Peruíbe - S.P.), Parque Estadual Ilha do Cardoso (Cananeia - S.P.), Chico Mendes Institute (ICMBio), andGeneticHeritage Management Council (CGen) for the research permits.

\section{References}

Andersen, R.A., and Kawachi, M. 2005. Traditional micoalgae isolation techniques. In Algal culturing techniques. Edited by R.A. Andersen. Esevier Academic Press. pp. 83-100.

AOAC. 1984. Official Methods of Analysis of the Association of Official Analytical Chemists. In 14th edition. American Public Health Association, Arlington.

Barka, A., and Blecker, C. 2016. Microalgae as a potential source of single-cell proteins. A review. Biotechnol. Agron. Soc. Environ. 20(3): 427-436. doi:10.1007/s00210-009-0433-9.

Becker, E.W. 1994. Microalgae Biotechnology and Microbiology. Cambridge University Press, New york.

Beijerinck, M.W. 1890. Kulturversuche mit Zoochlorellen, Lichenengonidien und anderen nie-deren Algen. Bot. Zeitung 47: 725-788.

Chen, C., Zhao, X., Yen, H., Ho, S., Cheng, C., Lee, D.-J., Bai, F.-W., and Chang, J.-S. 2013. Microalgae-based carbohydrates for biofuel production. Biochem. Eng. J. 78: 1-10. Elsevier B.V. doi:10.1016/j.bej.2013.03.006.

Chisti, Y. 2007. Biodiesel from microalgae. Biotechnol. Adv. 25(3): 294-306. Elsevier Inc. 
doi:10.1016/j.biotechadv.2007.02.001.

Chisti, Y. 2008. Biodiesel from microalgae beats bioethanol. Trends Biotechnol. 26(3): 126-131.

Christaki, E., Florou-Paneri, P., and Bonos, E. 2011. Microalgae: A novel ingredient in nutrition. Int. J. Food Sci. Nutr. 62(8): 794-799.

Fott, B. 1976. Choricystis, eine neue Gattung der Chlorococcales (Chlorophyceae). rchiv für Hydrobiol. Suppl. Algol. Stud. 49: 382-388.

Fott, B., and Nováková, M. 1969. A monograph of the genus Chlorella. The freshwater species. Stud. Phycol.: 10 74.

Gouveia, L., Evangelista, A., Lopes, T., and Reis, A. 2009. Neochloris oleabundans UTEX \# 1185: a suitable renewable lipid source for biofuel production. : 821-826.

Gouveia, L., and Oliveira, A.C. 2009. Microalgae as a raw material for biofuels production. J. Ind. Microbiol. Biotechnol. 36: 269-274.

Guedes, A.C., Amaro, H.M., Barbosa, C.R., Pereira, R.D., and Malcata, F.X. 2011. Fatty acid composition of several wild microalgae and cyanobacteria, with a focus on eicosapentaenoic, docosahexaenoic and $\alpha$-linolenic acids for eventual dietary uses. Food Res. Int. 44(9): 2721-2729.

Guillard, R.R.L., and Ryther, J.H. 1962. STUDIES OF MARINE PLANKTONIC DIATOMS. Can. J. Microbiol. 8(1140): 229-239.

Hartman, L., and Lago, R.C.. 1973. Rapid preparation of fatty acid methyl esters from lipids. Lab. Pr. 22(494): 475-477.

Hindák, F. 1980. Studies on the chlorococcal algae (Chlorophyceae). II. Biol. Práce 26: $1-195$.

Horrobin, D.F. 1992. Nutritional and medical importance of gamma-linolenic acid. Prog. Lipid Res. 31(2): 163-194.
Hu, Q., Sommerfeld, M., Jarvis, E., Ghirardi, M., Posewitz, M., Seibert, M., and Darzins, A. 2008. Microalgal triacylglycerols as feedstocks for biofuel production: Perspectives and advances. Plant J. 54(4): 621-639.

Huang, G.H., Chen, F., Wei, D., Zhang, X.W., and Chen, G. 2010. Biodiesel production by microalgal biotechnology. Appl. Energy 87(1): 38 46.

Komárková-Legnerová, J. 1969. The systematics and ontogenesis of the genera Ankistrodesmus Corda and Monoraphidium gen. nov. Stud. Phycol.: 75-144.

Korshikov, A.A. 1953. Viznachnik prisnovodnihk vodorostey Ukrainsykoi RSR [Vyp] V. Pidklas Protokokovi (Protococcineae). Bakuol'ni (Vacuolales) ta Protokokovi (Protococcales). : 1-439.

Kus, M.M.M., Silva, S.A., Aued-Pimentel, S., and Mancini-Filho, J. 2011. Nutrition facts of infant formulas sold in São Paulo state: assessment of fat and fatty acid contents. Rev. Nutr. 24(2): 209218.

Matos, J., Cardoso, C., Bandarra, N.M., and Afonso, C. 2017. Function Microalgae as healthy ingredients for functional food: a review. Food Funct. 8: 26722685. Royal Society of Chemistry.

Matsudo, M.C., Bezerra, R.P., Sato, S., Converti, A., and Carvalho, J.C.M. 2012. Photosynthetic efficiency and CO2 assimilation rate of Arthrospira (Spirulina) platensis continuously cultivated in tubular photobioreactor. Biotechnol. J. 7(11): 1412-1417.

Norton, T.A., Melkonian, M., and Andersen, R.A. 1996. Algal biodiversity. Phycologia 35(4): 308-326.

Ochsenreither, K., Glück, C., Stressler, T., Fischer, L., and Anderson, R. 2016. Production Strategies and Applications 
of Microbial Single Cell Oils. 7(October): 1-26.

Olaizola, M. 2003. Commercial development of microalgal biotechnology: From the test tube to the marketplace. Biomol. Eng. 20(4-6): 459-466.

Olguín, E., Galicia, S., Hernández, E., and Angulo, O. 2001. The effect of low light flux and nitrogen deficiency on the chemical composition of Spirulina sp. growth on pig waste. Bioresour Technol 77: 19-24.

Pérez-Mora, L.S., Matsudo, M.C., CezareGomes, E.A., and Carvalho, J.C.M. 2016. An investigation into producing Botryococcus braunii in a tubular photobioreactor. J. Chem. Technol. Biotechnol. 91(12): 3053-3060.

Piorreck, M., Baasch, K., and Pohl, P. 1984. Biomass production, total protein, chlorophylls, lipids and fatty acids of freshwater green and blue-green algae under different nitrogen regimes. Phytochemistry 23: 207-216.

Pulz, O., and Gross, W. 2004. Valuable products from biotechnology of microalgae. Appl. Microbiol. Biotechnol. 65: 635-648.

Ract, J.N.R., and Gioielli, L.A. 2008.
Modified lipids obtained from milk fat, sunflower oil, and phytosterols esters for application in spreads. Quim. Nova 31(8): 1960-1965.

Santos-zago, L.F., Botelho, A.P., and Oliveira, A.C. de. 2008. Effects of conjugated linoleic acid on animal metabolism: advances in research and perspectives for the future. Rev. Nutr. 21(2): 195-221.

Sauvageau, C. 1892. Sur les algues d'eau douce recoltées en Algérie pendant le session de la Societé Botanique en 1892. Bull. la Société Bot. Fr. 39: 104128.

Schlösser, U.G. 1982. Schlosser, 1982. Ber. Dtsch. Bot. Ges. 95: 181-276.

UTEX. (n.d.). The Culture Collection of Algae at the University of Texas at Austin. Available from http://www.sbs.utexas.edu/utex/ [accessed 3 September 2011].

Verlengia, R., and Lima, T.M. 2002. Síntese de Ácidos Graxos. In Entendendo a gordura: os ácidos graxos, Manole. Edited by R. Curi, C. Pompeia, C.K. Miyasaka, and J. Procópio. São Paulo. pp. 121-134.

\section{How to cite this article:}

Marcelo Chuei Matsudo, Célia Leite Sant'Anna, Lina Susana Pérez-Mora, Roberta Claro da Silva and João Carlos Monteiro de Carvalho. 2020. Isolation and Evaluation of Microalgae from Mangrove Area in South Coast of Sao Paulo (Brazil) for Lipid Production. Int.J.Curr.Microbiol.App.Sci. 9(06): 1293-1302. doi: https://doi.org/10.20546/ijcmas.2020.906.161 